\title{
Public Administration's Adaptation to COVID-19 Pandemic - Czech, Hungarian, Polish and Slovak Experience
}

\author{
Matej Horvat \\ Comenius University in Bratislava, Faculty of Law, Slovak Republic \\ matej.horvat@flaw.uniba.sk \\ https://orcid.org/0000-0002-8249-4029 \\ Wojciech Piątek \\ Adam Mickiewicz University in Poznan, Faculty of Law and Administration, Poland \\ wojtekp@amu.edu.pl \\ https://orcid.org/0000-0002-3494-1912 \\ Lukáš Potěšil \\ Masaryk University, Faculty of Law, Czech Republic \\ lukas.potesil@law.muni.cz \\ https://orcid.org/0000-0002-1797-6048 \\ Krisztina F. Rozsnyai \\ Eötvös Loránd University, Faculty of Law, Hungary \\ rozsnyaik@ajk.elte.hu \\ https://orcid.org/0000-0002-1494-5051
}

Received: 1. 3. 2021

Accepted: 29. 4. 2021

\section{ABSTRACT}

The pandemic of the infectious disease Covid-19 affected everyday life including public administration. In order to proceed with its duties, public administration had to adapt to these new and unprecedented conditions. The main goal of the article is to assess how public administration bodies adapted to the Covid-19 pandemic, especially in terms of the principle of the speed of procedure in the sense of the right to a fair trial within a reasonable time. In order to achieve this goal, the article focuses on public administration's adaptation to the pandemic from the perspective of the Visegrad Group countries (V4). It analyses the digitalisation of public administration in relation to delivery, speed of procedure, usage of new technologies, as well as several other areas of public life affected by the pandemic. Specific examples from all V4 countries are analysed and compared in order to identify which approaches were taken by public 
administration, how they changed the way public administration carried out administrative procedures, and which values were decisive for these changes. Based on these examples, the article concludes that the approach taken by respective legislatures and public administrations in the V4 region complies with the law, but also presents several exceptions.

Keywords: COVID-19, electronic communication, digitalisation of public administration, new technologies, principle of speed of the proceedings, public administration in V4 countries

$J E L: K 40$

\section{Introduction}

The coronavirus SARS-CoV-2 has caused a pandemic of infectious disease COVID-19. ${ }^{1}$ This pandemic has had an enormous impact on the everyday life of every person. It has already caused many damages from which the global economy will recover for many years to come. ${ }^{2}$

It would be a big underestimation to think that COVID-19 has not affected law and legal orders of countries on each continent. Legal order has had to adapt to the pandemic in order to achieve its operational and effective status. Many countries were not prepared for a pandemic that would either last for so long, nor would have such dire consequences. As a result, many legislators have faced a rather great challenge. Before COVID-19 pandemic, rules that governed everyday life of natural persons and legal persons usually stemmed from face-to-face interactions. However, mandatory lockdowns laid barriers in this respect and made it impossible to meet in person.

Respective legislators had to comply with this new situation. Since the legal order did not (and could not) anticipate such long lockdowns, the legal order had to adapt to this situation which then has led to a justified overproduction of legal regulations related to the pandemic.

For example, in 2020 the Slovak national legislator (National Council) passed 124 new statues or statutes' amendments. 48 (38,7 \%) statues (or amendments) of these 124 directly $^{3}$ tackled various aspects of COVID-19 pandemic in their respective provisions and 20 (16,1\%) of them were even directly named after COVID-19 pandemic. ${ }^{4}$ In 2021 (until 25 February), the legislator passed another 19 statues, 5 of them (26,3\%) related directly to COVID-19. ${ }^{5}$

1 See e.g. World Health Organisation. (2021). Coronavirus. At <https://www.who.int/healthtopics/coronavirus\#tab=tab_1>, accessed 7 January 2021.

2 See e.g. Chudik, A. et al. (2020). Economic consequences of Covid-19: A counterfactual multicountry analysis. At <https://voxeu.org/article/economic-consequences-covid-19-multi-country-analysis>, accessed 7 January 2021.

3 I.e. each of these statutes (or amendments) regulated new or amended provisions directly associated with COVID-19 pandemic.

4 E.g. Act No. 67/2020 Coll. on certain emergency measures in finance relations related with the spread of the dangerous contagious human disease COVID-19.

5 The statistics are derived from the official Slovak collection of laws available at <https://www. slov-lex.sk/domov>, accessed 25 February 2021. For more information about Slov-lex in Eng- 
The Polish legislator passed one general statute connected with the impact of the pandemic on the whole society and various spheres of state functioning, ${ }^{6}$ however this statute was amended many times. ${ }^{7}$ Beside this one general act, several more detailed statutes concerning assistance for entrepreneurs ${ }^{8}$ or electronic deliveries ${ }^{9}$ were passed. In Czech Republic in 2020 the Parliament passed 141 new statutes or statutes' amendments. 35 (25\%) statutes (or amendments) dealt with various aspects of COVID-19. In reality "only" 24 of them were new legislative acts, the rest (11) were amendments regarding this new COVID-19 legislation. By the end of February 2021, a new pandemic law of general nature passed in Czech Republic. Majority of mentioned legislation regulates different compensations, namely for businessmen. It is worth mentioning that it was mainly the public administration (the government and especially the Ministry of Health) who issued large amounts of different decrees and normative acts containing different restrictions, duties, etc. in the struggle with the COVID-19 pandemic. ${ }^{10}$ In Hungary, it was the government who decided on the emergency situation but as this could not last long, Parliament helped mainly by incorporating all the rules the government introduced into statutory law or prolonging the effect of government decrees (Hoffman and Balázs, 2021), the latest such act was Act No I. of 2021. Only approx. 4\% of statutes were connected directly to the emergency situation or the pandemic. The extraordinary measures of the chief medical officer only played an intermediary role between the expiry of the first emergency status and the changing of the rules of the Act on Disaster Management on the emergency state by the Parliament (Hoffman and Balázs, 2021).

lish see <https://www.slov-lex.sk/web/en>.

6 The statute from 2 March 2020 about special solutions related to the prevention, counteraction and combating COVID-19, other infectious diseases and emergencies caused by them (Journal of Laws 2021, item 1842 as am., hereinafter only as "statute from 2 March 2020").

7 The last amendment is from 21 January 2021 (Journal of Laws 2021, item 159). As a result, some articles of the statute from 2 March 2020 have received complicated numeration, e.g. article $15 z z z z z n 1$, which is not in conformity with the principle of clarity of legal texts.

8 One of these acts passed on 16 April 2020 (Journal of Laws 2020, item 695 as am.). On its basis, entrepreneurs could have applied for assistance during the first wave of pandemic.

9 The statute from 18 November 2020 on electronic deliveries (Journal of Laws 2020, item 2320) will come into force on 1 July 2021. It will amend the basic law about pandemic in Poland from 2 March 2020 in the area of delivery.

10 The statistics are derived from the official Czech collection of laws available at <https://aplikace.mvcr.cz/sbirka-zakonu/SearchResult.aspx?q=2020\&typeLaw=zakon\&what=Rok>, accessed 23 February 2021. 
Table 1: Acts of Parliament, government and ministries regarding COVID-19

\begin{tabular}{|c|c|c|c|c|}
\hline & $\begin{array}{c}\text { Acts of } \\
\text { Parliament } \\
\text { connected } \\
\text { directly to the } \\
\text { pandemic }\end{array}$ & $\begin{array}{c}\text { Acts of } \\
\text { Parliament } \\
\text { from mid- } \\
\text { March } 2020 \\
\text { (until March } \\
\text { 2021) }\end{array}$ & $\begin{array}{c}\text { Government } \\
\text { Decrees (and } \\
\text { normative } \\
\text { decisions) } \\
\text { connected } \\
\text { directly to the } \\
\text { pandemic }\end{array}$ & $\begin{array}{c}\text { Ministerial } \\
\text { decrees (and } \\
\text { normative } \\
\text { decisions) } \\
\text { connected } \\
\text { directly to the } \\
\text { pandemic }\end{array}$ \\
\hline $\begin{array}{r}\text { Czech } \\
\text { Republic }\end{array}$ & 37 & $141(113)$ & $21(+183)$ & $\begin{array}{c}5(+227 \\
\text { extraordinary } \\
\text { measures of } \\
\text { Ministry of } \\
\text { Health) }\end{array}$ \\
\hline Hungary & 6 & 179 (166) & $108(+64)$ & $9(+2)$ \\
\hline Poland & 21 & $144(117)$ & 96 & $82(+15)$ \\
\hline Slovakia & 53 & $147(142)$ & 44 & 12 \\
\hline
\end{tabular}

Source: authors

Although statutes represent the most important legal framework that any person has to follow, executive power and, more precisely, public administration is responsible for its exercise in accordance with the law (c/F Škultéty et al., 2005, p. 12; Košičiarová, 2015, p. 61; Barabás et al., 2018) and, if needed be, for its enforcement. Public administration has also faced several challenges during the COVID-19 pandemic even though public administration leads most of its procedures in written form (c/F Vrabko et al., 2019, p. 54).

Based on several examples of how public administrative bodies coped with this situation, the purpose of this article is to formulate proposals on how public administrative bodies could and should change the way they carried out administrative procedure. The aim of this change was to adapt to unprecedented conditions raised by the pandemic along with maintaining the speed of procedure in terms of right to a fair trial within a reasonable time. Achieving this goal will help build more trust to public authorities. We will present several examples of practice in which Czech, Hungarian, Polish and Slovak public administrative bodies fully upheld rights associated with fair trial requirements and therefore they suitably faced COVID-19 pandemic. However, we will also present examples where public administration did not achieve this standard. These suggestions will mostly discuss efficient and quicker execution of administrative procedures in respective country, i.e. Czech Republic, Hungary, Poland and Slovakia (hereinafter only as "V4 countries"). This approach has yet not been tackled in literature. From the legal point of view that concerns public administration, authors focused on states of emergency (Binder et al., 2020; Scalia, 2020), bans of in-person attendance at board 
meetings (Allen, 2020), immigration (Wadhia, 2020), or judicial review in the administrative court (Tomlinson et al., 2020).

In the first part of the article we will shortly present methodology that will allow us to propose correct conclusions for the article and its aim. The second part of the article will analyse examples of good practice as well as malpractice of public administration regarding administrative procedures during COVID-19 pandemic. In the final part of the article we will discuss our conclusions.

\section{Methods}

From the methodological perspective, we applied several methods of scientific research used in legal texts, therefore our approach will evaluate only legal point of view concerning public administration. The right mixture of these methods would lead to achieve the goal of this article. The main goal of the article is to assess how public administration bodies adapted to the COVID-19 pandemic, if and how their approach changed from the perspective of carrying out administrative proceedings and which values were decisive for these changes.

This research consisted of analysis of laws in force in V4 countries and of analysis of professional literature. The research also consisted of gathering an empiric knowledge. The research conducted use of different research methods, especially the dogmatic and comparative method. The dogmatic or blackletter ${ }^{11}$ method focuses on determining what the law is on a particular point. It involves locating and interpreting relevant primary and secondary sources of law and synthesising those sources to form a rule or rules of law (Taylor, 2014). The dogmatic method facilitated an analysis and interpretation of the current law and its amendments and the formulation of conclusions related to the phenomenon that we researched.

The method of analysis was used to analyse approaches of V4 legislators taken as a reaction to the pandemic, i.e. we had to utilize data already available and analysed it to make a critical evaluation of the information gathered (Al Amern et al. 2020, p. 51). From the general perspective of legal theory, we also analysed functions and methods of public administration. The intention of a theory is to summarize existing knowledge to provide an explanation on the observed events by exposing the relations embodied in the conceptual framework (Pradeep, 2019, p. 100). Based on the analysis of V4's legislators approach, the article focused on interrelationships between approaches that V4 countries have taken to battle the COVID-19 pandemic. In order to do so, the article compared legal regulations of all respective V4 countries. With the application of comparative method, various legal systems have been analysed together to identify the similarities and differences in terms of their effectiveness in providing legal protection, the quickness of the proceedings and their simplifications due to special legal and factual conditions which have arisen in the pandemic. The comparative method has helped to create diverse

11 The term 'black letter' refers to research about the law included in legislation and case law. The term originated from the name of the Gothic type which continued to be used for law texts (Hutchinson and Duncan, 2012, p. 94). 
solutions for shared problems that are regulated differently by different national legal systems.

The paper does not contain a primary research and given the fact that at the moment no papers addressing the topic of this paper аге available, we used secondary data instead from publicly available sources (such as newspapers articles), but also from informal discussions with employees of public administrative bodies concerning the topic of delivery. On this basis, we arrived at conclusions regarding the operations of the public administration of V4 countries. In this way, we got a common background on V4 countries approaches to battling the pandemic. It gave us a suitable knowledge board to answer the main research question. This last point of view was tackled based on method of induction. Induction is often described as drawing inferences from specific observable phenomena to general rules, or "knowledge expanding." Неге, evidence is collected about observable events and a premise is constructed based on the collected data (Worster, 2014, p. 448). The use of method of induction is justified as it allowed us to state general conclusions based on the evaluation of basic scientific data that arose from our analysis and comparison. Therefore, the method of induction was used mainly in discussion and the concluding part of the article.

\section{Public administrative bodies and their stance against the COVID-19 pandemic}

Rule of law principle applies to public administration regardless of ongoing pandemic and adopted emergency measures. Rule of law principle requires that all decisions and activities of public administration bodies have to arise from legal regulation, their content have to comply with legal regulation and could be effectively enforced (decision of the Supreme Court of Slovak Republic file No. 3 Sžo 202/2015 from 3 August 2016. Similarly, see the decision of the Supreme Administrative Court of the Republic of Poland file No. II OSK 3253/18 from 20 March 2019). While issuing decisions and performing other tasks, public administrative bodies have to proceed in a way that complies with law so that the content of their decision complies with legal regulation. Legal regulation on competences and tasks of public administration bodies have to be stipulated clearly and specifically (decision of the Regional Court in Trnava file No. 14 S 73/2013 from 12 June 2014). Case law fully supports the idea of rule of law principle as a leading principle that binds public administration. The rule of law principle manifests itself in all activities of public administration, in all its tasks, functions, methods or forms as they all derive from legal regulation (c/F Merkl, 1931, p. 173).

Tasks of public administration during any pandemic are to maintain public order, public health and proper functioning of the state.

In all V4 countries, legal scholars stress two important functions of public administration: the regulatory function and the safeguarding function (Machajová et al., 2009, pp. 125-126; Niewiadomski, 2010, pp. 21-22; Sládeček, 2019, 
p. 30; Rixer, 2014, p. 83). The regulatory function aims at the arrangement of public administration bodies and natural and legal persons as well as other public administration organs and relationships between them. The safeguarding function aims at securing a smooth exercise of public administration and also arrange for the provision of means of remedy against the exercise of power. This function is not only supplementary but also proactive. Both of these functions overlap and complement each other (Prưcha, 2007, pp. 255256). This is clearly visible during the pandemic as public administration has exercised both functions.

The functions of public administration manifest themselves in principles of how public administration performs itself in each country. Apart from rule of law principle, the principle of subsidiarity of exercise of public authority is extremely important. The essence of this principle is that a public authority should intervene into the legal status of natural and legal persons only to the smallest possible extent. Public authority may be used only if the public body cannot achieve the desired state by any other means (Cepek et al., 2018, pp. 70-71; Barabás et al., 2018; Skulová et al., 2020, pp. 69-70). ${ }^{12}$

One of the consequences of applying this principle affects the choice and usage of methods of the exercise of public administration's activities. Legal theory widely states that persuasive methods should be used primarily while coercive methods only secondly (Škultéty et at., 1997, pp. 70-71; Skoczylas and Piątek, 2020, pp. 471-472). While it takes shorter time to use methods of coercion, the effects of persuasion methods last longer. This is ascribed to the fact that once a person ${ }^{13}$ is persuaded to act in a certain way (i.e. to make, abstain, or endure), this person will voluntarily fulfil his/hers obligations (Vrabko et al., 2018, p. 135). An adoption of persuasive methods leads to strengthening trust towards public administration which will have crucial importance also in post-pandemia proceedings (Ansell, Sørensen and Torfing, 2020, p. 11).

It is equally important to say that the state should choose methods that are effective in achieving a desired goal, appropriate to the circumstances and at the same time interfere only to the extent necessary with fundamental rights and freedoms (Havelková, 2020). An emergency situation may affect the balance of rights and obligations making reasonable and proportionate solutions that under ordinary conditions would be greatly unreasonable and disproportionate (Scalia 2020, p. 106). In such conditions public administration is not free from building trust and understanding for its decisions. An adoption of intransparent, unprofessional and provisory solutions can lead to opposite effects (Di Mascio, Natalini and Cacciatore 2020, p. 625).

If legal theory states that public administration is in fact a service to the public carried out in favour of public interest (cf. Hendrych et al., 2009, p. 5; Kopecký, 2019, p. 6; Fazekas, 2020, p. 25), then we distinguish two intertwine

12 For further analysis of binding principles of public administration see e.g. Košičiarová, 2015, pp. 71-83.

13 By person(s) we mean any natural person or legal person as addressee of public administration. 
approaches of handling COVID-19 pandemic within the V4 region. One being more formal according to which activities of public administration had to firstly be stipulated by law and another less formal where activity of public administration arose from the use of persuasive methods aimed at safeguarding legal status of persons that would not interfere with their protected rights.

In order to support this claim, we will discuss several examples in the following text. Firstly, we will address the common approach of public administration of all V4 countries. Then we will focus on different approaches that V4 countries and the public administration used to tackle the COVID-19 pandemic.

\subsection{Digitalisation of public administration in relation with delivery}

Public administration in all V4 countries currently undergo a series of steps related to its digitalisation. However, various levels of digitalisation have been reached in the respective countries. Digitalisation of public administration is important from the point of view that it helps to abide the "new normal" life of working from home and being on lockdown. Especially electronic delivery helped public administration adhere to the principle of speed of the proceedings and the right to a fair trial within a reasonable time.

\section{Chart 1: The augmentation of the number of e-databoxes in relation to population ${ }^{14}$}

The augmentation of the number of e-databoxes in relation to population

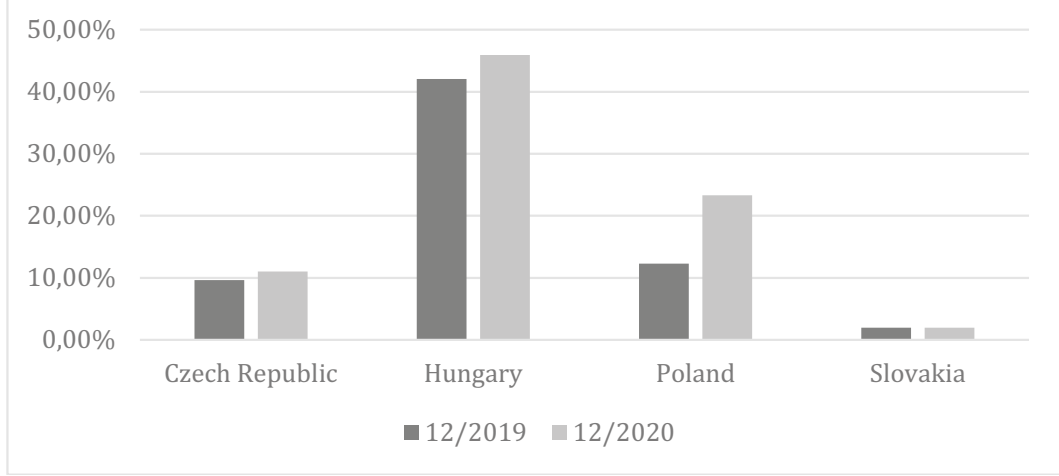

Source: own interpretation based on data from Czech Republic at <https://www. datoveschranky.info/statistiky>, accessed 1 March 2021; Hungary at: <https://regi. ugyintezes.magyarorszag.hu/dokumentumok/mohustat.xls>, accessed 26 February 2021; Poland at: At <https://www.telepolis.pl/wiadomosci/prawo-finanse-statystyki/ profil-zaufany-ma-juz-7-milionow-polakow>, accessed 23 February 2021; Slovakia at: <https://www.nases.gov.sk/wp-content/uploads/2020/12/vyrocna-spravaNASES-2019.pdF>, accessed 12 January 2021.

14 Data for 2020 in Slovakia are not available at the moment; while in other V4 countries the data on used and unused electronic boxes are up to date, the data from Slovak Republic are 
In Czech Republic, from the point of view of the use of forms of electronic communication by the administrative bodies, it must be noted that administrative bodies were relatively well prepared for the new situation. Since 1 July 2009, the electronic delivery is obligatorily carried out to data boxes. ${ }^{15}$

All public authorities, including administrative bodies, are obliged to use their data boxes. If any addressee has a data box set up, it is the duty of the administrative body to deliver it exclusively in this way, otherwise the delivery is unlawful. The data box must be set up by almost all legal entities, as well as specific professions, such as advocates or tax advisors. In addition, non-business individuals can also voluntarily request the establishment of a data box. Given that the Czech public administration had already long-term experience with this delivery system, this new requirement was not a significant obstacle. ${ }^{16}$ In some specific cases (especially tax administration) it is even prescribed for those who set up a data box to use it exclusively in communication with administrative bodies.

In Hungary, the situation was somewhat alike, as digitalisation of communication of public administrative bodies with each other as well as with the persons affected by their activity was a chief aim of Hungarian public policy for the last decade (Baranyi et al., 2018). So, when the pandemic hit in, the most important areas were already using electronic communication - including the delivery of administrative decisions - as the obligatory mode of communication. After long preparation, the Act on Electronic Administration and Services was promulgated at the end of 2015 which started the process of transforming communication in administration significantly. There was a lot of government investment and development in these communication systems backed by regulations creating in more and more areas either obligations to use electronic administration or persuading stakeholders to change to eadministration. These developments form a matrix of "regulated electronic administration services", all elements which can be put together to "service kits" to provide electronic administration (Baranyi et al., 2018). One of these elements is the "surface for personalised case handling" (SZÜF) where more than 680 types of administrative cases can be handled by all natural and legal persons who have a "client gate" - another element of this matrix. In 2019, the Hungarian legislator obliged all legal persons as well as legal representatives to use the electronic communication system through a "company gate" both in administrative and in court procedures. At the end of spring 2019 there were already 550000 such company gates and 13200 legal persons of state and local government had an "office gate" on the other side. These gates are the three main points of entering electronic communication with

from 2019 as there is no newer data available at the moment. This could be seen as another sign of undeveloped e-government in Slovakia.

15 Act No. 300/2008 Coll. on Electronic Acts and Authorized Conversion of Documents

16 Until 21 February 2021 more than 1.2 million data boxes had been set up, within which over 840 million data messages had been sent. The success rate was $99.57 \%$. 
public authorities. ${ }^{17}$ Already in 2019, on average 17 million documents were handled in this way. ${ }^{18}$

For natural persons, there was a very important incentive to use this system as since 2017 the tax authority is preparing the draft of the tax declaration for personal income revenue, which is delivered to the repository of the taxpayer who can either accept this draft or amend it in a simple way online and send it back as well as pay additional tax due directly in this system. The persuasive method used here resulted in a significant augmentation in the last years to 4.2 million client gates in February $2020 .^{19}$ In other sectors, obligatory digitalisation is also present heavily, for example in building and construction law where all applications and notifications - together with all plans - have to be submitted since several years typically through an internet platform.

Under the pandemic, this trend continued: actually there are more than 4.5 million client gates and 618945 company gates. ${ }^{20}$ What is even more important, the number of electronic case handling shows an enormous raise from averagely 336000 cases per month to 1.2 million cases handled showing the persuasive role of the pandemic also in lack of a general obligation to deliver electronically in the General Administrative Procedure Act. It shows on the one hand that private persons use this form more and more. On the other hand, it may be in a smaller part due to a trend of augmentation of official organs joining the electronic communication system who are not obliged to do so. The number of office gates continuously augments, from 13915 in January 2020 to 14531 in January 2021. This affects mostly vocational chambers and other organisations who exercise state functions but are not obliged to electronic communication with members and other parties as not being administrative organs. The greatest rise in the numbers of entries (visits) to the electronic system from a monthly average of 900000 to 5 million as well as in the number of entries to the electronic email-box for the downloading of official documents delivered this way to 34 million $^{21}$ may be due to the single electronic health service system digitalisation of prescriptions and medical documentation.

In Poland, the pandemic has affected the procedure of deliveries, too. On the basis of the statute from 2 March 2020 it is possible to grant parties of the proceedings the access to administrative files electronically. It is even not necessary to have an Electronic E-Mail Box protected by individual login and created on a platform of public administration. Such possibility of a contact with public administration was created in Poland already in $2005^{22}$ and is becoming more and more popular. In February 2020 there were more than 5

17 There is also a distinct "process-gate" for the communication with courts, which is important for our topic in relation to administrative court procedures.

18 With peaks in "taxation months" of 22 or even 25 million documents.

19 This number at present is almost equal with the number of working people (4 496100 in November 2020 according to the National Office for Statistics).

20 Statistics retrieved from <https://regi.ugyintezes.magyarorszag.hu/dokumentumok/mohustat.xls>, accessed 26 February 2021.

21 Statistics retrieved from <https://regi.ugyintezes.magyarorszag.hu/dokumentumok/mohustat.xls>, accessed 26 February 2021.

22 The legal basis was the statute from 17 February 2005 on Digitalisation of Public Administration Obligations (Journal of Law 2020, item 346 as am.). 
million people $(13,1 \%$ of the whole population) in Poland who activated this profile. ${ }^{23}$ In June 2020, it was already more than 7 million citizens $(18,4 \%){ }^{24}$ During the pandemic, a party of the proceedings can request the public authority to send files on a private E-Mail Box. Based on article 15zzzzzn Nb 2 of the statute from 2 March 2020, a public authority is not obliged to fulfil the party's request but concerning the rule of law a rejection should be justified (Szewczyk, 2020, p. 26).

It is understandable that for those who stay in quarantine deliveries should be gathered in post offices and should not be send back to the sender. The pandemic enriched various parts of official deliveries in hybrid delivery. If the addressee will give the approval to the Polish Post, then it is possible to deliver the addressee a scan of the original document sent by public administration authority which is opened in a post office. The scan has the same official authorisation as the original. This service is free for citizens however it is not popular as many people are afraid of violation of secrecy of correspondence. ${ }^{25}$ Gradually, in Poland this kind of hybrid delivery will be improved since 1 July 2021 when the Act on Electronic Deliveries will come into force. It will be obligatory for public entities, including legal attorneys. Currently, the details on the hybrid delivery raise more questions than answers. At the Hungarian Post and Slovak Post, there are no such developments. ${ }^{26}$

In Slovakia, a general rule on electronic delivery is that persons can communicate with public administration bodies by using electronic boxes only. The use of electronic boxes is preferred because it guarantees identity and unity of a person who communicates with a public administration body. Only the owner of the electronic box may log-in into the electronic box by using his/hers e-ID. This means a certainty that only this person submitted a motion, notification, statement, etc. and not someone else.

However, according to National Agency for Network and Electronic Services' Annual Report $2019^{27}$ out of 5047690 electronic boxes of natural persons only 105919 are activated and therefore suitable for electronic communication. It means that only $2,1 \%$ of eligible natural persons are able to communicate electronically with public administrative bodies. Administrative Procedure Act (Act No. 71/1967 Coll.) stipulates a general rule pursuant to which if a person makes a submission in electronic form but not via electronic box (e.g. via e-mail), that person must confirm submitting the submission in paper form, orally into the

23 Official database of the Ministry of Digital Affairs. At <https://www.gov.pl/web/cyfryzacja/ ponad-5-milionow-polakow-ma-juz-profil-zaufany>, accessed 23 February 2021.

24 Official database of the Ministry of Digital Affairs. At <https://www.telepolis.pl/wiadomosci/prawo-finanse-statystyki/profil-zaufany-ma-juz-7-milionow-polakow>, accessed 23 February 2021.

25 Electronic deliveries are necessary but it can violate privacy and secret of correspondence $<$ <ttps://www.prawo.pl/prawo/doreczenia-elektroniczne-potrzebne-ale-moga-naruszac-prywatnosc,499522.html>, accessed 23 February 2021.

26 However, in Hungary there is in the e-administration also a central receipt system since 2015 with 580 public organisations adhering to it already in 2019. Paper-based items sent to this system ("E-Papír") are transformed and then delivered electronically.

27 Národná agentúra pre siețové a elektronické služby. (2020). Výročná správa 2019. At <https:// www.nases.gov.sk/wp-content/uploads/2020/12/vyrocna-sprava-NASES-2019.pdf>, accessed 12 January 2021. Annual Report 2020 has not been published yet. 
minutes or via electronic box. ${ }^{28}$ It is clear that oral version of confirmation is not possible at the moment of pandemic.

Coincidently, in Slovakia the first wave of COVID-19 pandemic overlaid with deadlines to submit tax declaration. ${ }^{29}$ Act No. 563/2009 Coll. on Tax Proceedings stipulates that missing a deadline to submit a tax declaration is an administrative offense [art.154(1)(a) of this act] for which a tax body may impose a fine between 30 EUR to 16000 EUR [art. 155(1)(a) of this act]. ${ }^{30}$

In general, employers submit the tax declaration of income tax for all their employees. However, if an employee has an income from more than one employer, the obligation to submit the tax declaration falls to the employee.

In order to ease the pressure of the pandemic, the legislator passed a new law - Act No. 67/2020 Coll. on Certain Emergency Measures in Finance Relations Related with the Spread of the Dangerous Contagious Human Disease COVID-19 (hereinafter as "Act No. 67/2020 Coll."). Act No. 67/2020 Coll. is interesting from two points of view.

First, Act No. 67/2020 Coll. postponed deadlines to submit tax declarations. This act stipulated that measurements according to this act are in force from 12 March 2020 when the government introduced the state of emergency up until the end of the month when the government will call off the state of emergency. For the sake of completeness, based on amendment of Act No. $67 / 2020$ Coll. the measurement of postponing the submission of tax declaration ended on 31 September 2020.

Second, Act No. 67/2020 Coll. also enacted a temporary solution regarding electronic communication in its art. 3. Pursuant to art. 3(1) if a submission is made by electronic means but not in a manner pursuant to a special regulation, it is not necessary to deliver the submission in paper form. Such submission shall be deemed as received. This rule means that if a person chooses to submit a motion, notification, statement, etc., the person may use even his personal email to send the document. However, Act No. 67/2020 Coll. does not allow to send the mail to any email address of, for example, any tax body employee. The e-mail has to be addressed to the official e-mail address of the tax body itself.

This solution enables to communicate with the tax body in a smoother way and unburdens from the obligation to use the electronic box. We have to stress that this way of communication is allowed only in tax proceedings and therefore is not available in any other type of administrative proceedings such as proceedings on administrative offence, or building permission, etc.

In order to make clear on how the tax body shall respond to any electronically sent submissions, Act No. 67/2020 Coll. stipulates that the tax body is obliged

28 Art. 19(1) of Act No. 71/1967 Coll. Administrative Procedure Act as amended.

29 In terms of tax declaration for income tax of natural persons - 30 March and in terms of tax for real estate tax within February till May depending on delivery of decision on real estate tax in which a specific amount of tax is calculated.

30 In terms of real estate tax, the maximum fine is up to the amount of tax itself, however not less than 5 EUR and not more than 3,000 EUR. 
to use the same way of communication as the person chose in the first place [art. 3(2) of this act]. If a person choses a Gmail account, then the tax body replies to this Gmail account. This applies to situations when, e.g., the motion is incomplete because of missing annexes, etc. and the tax body must inform the person of this.

Act No. 67/2020 Coll. also stipulates an exception when a tax body is obliged to communicate in paper form. This applies to decisions issued by a tax body. Decisions have to be delivered in paper form into addressee's own hands [art. 3(3) in conjunction with art. 5(1)].

This example is suitable for the first mentioned approach when public administration bodies firstly had to have an appropriate legal regulation to act in a certain way. Without legal regulation stipulated within Act No. 67/2020 Coll. the public administration could never use emails to communicate with persons.

\subsection{Principle of speed of the proceedings (deadlines and related issues)}

Previous part of the article pointed out that electronic delivery helped public administration upheld the principle of speed of the proceedings. On the other hand, where electronic delivery was not applicable, serious breaches of this principle could occur. Therefore, legislators and public administration had to address questions related to deadlines to issue a decision.

In Czech Republic, unlike courts and court proceedings, ${ }^{31}$ for the area of public administration and administrative procedure, no legal regulation has been adopted, which would e.g. allow for the extension of deadlines that were missed by natural or legal persons due to the COVID-19 pandemic. The reason is, among other things, the fact that such a general possibility is already regulated in article 41 of the Administrative Procedure Code (Act No. 500/2004 Coll.) It was possible to use it even during a pandemic. Not a single amendment to the Administrative Procedure Code was adopted which would tackle the COVID-19 pandemic, e.g. regarding the possibility of conducting oral proceedings in electronic form or to have access to the files online. Indeed, the consequences of the COVID-19 pandemic were that the mandatory or ordered oral hearings had to be postponed (mostly due to excuse from disease or ordered isolation) and the deadlines for issuing decisions had to be extended. Some officials were transferred to perform other agendas related to the payment of a number of compensations, etc. Unfortunately, the Czech public administration has long and negatively manifested itself in the absence of various data, which is why it is not possible to substantiate these general conclusions in any way. Overall, the weak digitalisation of public administration has manifested itself. Coincidentally, even before the outbreak of the COVID-19 pandemic, a basic legal framework was created for the later digitalisation of the Czech public administration. ${ }^{32}$

31 Act No. 191/2020 Coll.

32 Act No. 12/2020 Coll. on the Right to Digital Services. 
In Hungary, the situation was very similar. Whereas there was detailed regulation for court procedures, mainly aimed at reducing personal contacts, for administrative authoritative procedures there were no general rules adopted despite the augmentation of administrative cases in some fields (Hoffman and Balázs, 2021). There were rather strategies for avoiding administrative cases. On the one hand, in registry cases (certificates, carnets, attestations like ID cards, driving licences or vehicle papers for roadworthiness, etc.) the expiry date of documents was extended for after the end of the emergency situation. On the other hand, this avoidance meant the continuation of the tendency that started with the debureaucratization programmes of the government in 2015. In this process, using the means of the transposition of the EU Service Directive (Directive 2006/123/EC of the European Parliament and of the Council of 12 December 2006 on Services in the Internal Market), namely the changing of authorisation schemes. Instead of submitting an application for a permit, in numerous administrative cases, it is enough to notify the authority about the starting of an activity, and the authority has a wide margin of appreciation to decide upon this notification, whether it wants to start an authorisation procedure or accepts the notification and with its - lawful - silence practically grants the permit. The problem with this scheme is, that as there is no procedure in most cases, the interests and rights of counter-interested parties cannot be observed nor can the participation of the interested public be granted (Hoffman and Balázs, 2021) as well as problems regarding the lawfulness of a notified activity can arise later in other administrative (court) procedures. This causes heavy deficits not only in regard of the safeguards of administrative procedures, but also in judicial protection as without a decision or an unlawful silence judicial review cannot be initiated, counter-interested parties and NGOs can only sue those who act upon these notifications before civil courts which is long and expensive as well as rarely resulting in real redress. The surveillance authorities do not show much activity in initializing ex officio procedures when the activity is exercised in a wrongful way. Besides these changes, the so-called conditional decision, the main means against the unlawful silence of administration - although it was one of the first institutions introduced with the debureaucratization programme (F. Rozsnyai and Hoffman, 2020) - was also abolished.

Within the first wave of pandemic, the Polish legislator decided to suspend material and procedural terms in administrative law relevant to prescription, administrative silence and time limits for administrative proceedings. Many legal actions, like the complaint against inactivity of public administration, were not possible to file. Additionally, this regulation which was introduced in the statute from 2 March 2020, was later amended by statute from 31 March $2020^{33}$ that came into force on the date of the introduction of a state of epidemic threat which was already announced on 14 March 2020. Up until today, the jurisprudence of the administrative courts is not uniformed when it comes to the issue of the retroactivity of these norms. From one side, the suspension of terms was introduced in favour of interests of individuals who had more

33 The statute from 31 March 2020 on the amendment of the statute from 2 March 2020 and other statutes (Journal of Laws 2020, item 568). 
difficult access to public institutions since the first half of March 2020. ${ }^{34}$ From another point of view, the retroactivity breaches principle of legal certainty. ${ }^{35}$

In autumn 2020, the suspension of terms was not repeated by the Polish legislator. Only for individual purposes, if a public authority becomes unable for timely settling disputes, it could inform all citizens about time prolongation which can last no more than 30 days. This rule seems to be more logical, because time inactivity is not binding for all public bodies, but only for the respective authority that due to pandemic reasons needs more time for case settlement. The principle of speed of the proceedings is protected in a more suitable way.

The pandemic is not treated in the jurisprudence as an automated reason for a reinstatement of a time limit in administrative proceedings. ${ }^{36}$ Especially if the pandemic lasts months, it is difficult to prove to public authorities and administrative courts that it was not possible to organize various obligations in order to keep procedural terms. Nevertheless, if a party of the proceedings omitted a term from which depends this party's right, a public authority should inform this party about the possibility to file a motion for a reinstatement of time.

In Slovakia, as mentioned, during COVID-19 pandemic it has not been easy for persons to stay in contact with employees of public administrative bodies. Due to undeveloped e-government, the citizens could have faced an issue of public administration silence. Resulting from mandatory lockdowns, employees of public administrative bodies had to stay at home. In better circumstances they were able to work remotely (from home) via VPN links/connections. In worse case circumstances, they could not work remotely as many public administrative bodies still do not keep administrative files in electronic forms which are remotely accessible. This practice has led to delays in administrative procedures and therefore interfered with the right to a fair trial within a reasonable time [see especially art. 6 of European Convention on Human Rights, but also art. 48(2) of Constitution of Slovak Republic].

Unlike in the court proceedings, administrative proceedings were not amended in favour of either public administrative bodies or participants of the proceedings in terms of prolongation of deadlines. The only exception was (the already mentioned) legal regulation in tax law.

In other areas of administrative procedures, no amendments were enacted despite the fact that legislative solution would be beneficial. To be specific, in the last couple of weeks, through informal discussions led with public servants, one specific issue came to light in relation to difficulties with delivering abroad. As a result of this, bringing administrative proceedings to an end is often impossible as the decision might not come to legal force without a

34 See the orders of the Supreme Administrative Court from 13 October 2020, signature II OZ $762 / 20$, from 14 October 2020, signature II GSK 905/20, from 11 December 2020, signature II GZ 368/20. At <orzeczenia.nsa.gov.pl>, accessed 23 February 2021.

35 See the orders of the Supreme Administrative Court from 1 December 2020, signature I OZ 961/20, from 3 December 2020, signature II FZ 510/20, from 27 January 2021, signature I FZ 282/20. At <orzeczenia.nsa.gov.pl>, accessed 23 February 2021.

36 See the order of the Supreme Administrative Court from 5 February 2021, signature II FZ 2/21. At <orzeczenia.nsa.gov.pl>, accessed 23 February 2021. 
confirmation on successful delivery from a postal service company. Lockdown caused one certain issue since one of its consequences was that deliveries abroad "stayed" on borders between states. In practice, given many regulations safeguarding the public health, subsequent redistribution of deliveries did not take place for several weeks. Simply put, "there was no one to pick them up and deliver". Although public administrative bodies issued decisions on time, the administrative proceedings could not obtain its effects as the decisions were not delivered. This issue befell especially into various building proceedings (mostly building permission proceedings).

Nowadays, legal regulation offers solution only to the cases where either the parties to the proceedings are unknown to the administrative body or administrative body does not know the address of the participant. If such situation occurs, the administrative body is not obliged to deliver into the addressee's own hands, but, instead, might use delivery via public notice. However, this is not the case as the administrative body knew who the parties were and also knew their delivery address. As a result, in this case, public administration did not come up with any solution that would overcome the issue.

\subsection{Public administration and new technologies during pandemic}

As follows from the above, public administration has been (and is forced) to face challenges in the form of the use of new technologies to provide its services.

In Czech Republic, this was also significant in connection with the meetings of the bodies of local self-government units. These were first limited, respectively transferred to the online environment ${ }^{37}$ and subsequently allowed to take place, but under strict hygienic conditions. ${ }^{38}$ In Slovak Republic, the same issue occurred. The solution came in the form of amending the Act on Municipalities (Act No. 369/1990 Coll.). Based on the amendment of the Act on Municipalities (Act No. 73/2020 Coll.) the legislator stipulated that during the state of emergency declared in connection with the COVID-19 pandemic, the municipal council meetings may occur by means of a videoconference or by any other means of communication technology. The municipality must record the meeting either as an audio/video format or only as an audio format. If the municipality has its official website, then within 48 hours after the end of the meeting it must publish the recorded meeting on the website. This record is available to anyone immediately after the end of the meeting. Municipality must also publish a written record of the meeting on its official notice board. In Hungary, there was no such development, which is due to the rather unfortunate rule of the National Disaster Act, that in emergency situations the mayor can decide in the place of the local council, which was handled in different ways. Some mayors introduced preliminary consultations with the members of the councils and decided according to the outcome of these, whereas

37 Government decree of 23 March 2020 No. 274 issued as No. 122/2020 Coll.

38 Government decree of 6 April 2020 No. 388, issued as No. 151/2020 Coll. ensuring distances of $2 \mathrm{~m}$ and the use of respiratory protective equipment. 
other mayors did not and even misused their powers to make decisions they could not get through the councils before (Hoffman and Balázs, 2021). ${ }^{39}$

Czech Republic encountered problems with access to the files. The absence of electronic files was often dealt with by officials by scanning and sending them by e-mail in order to have access to the files. On the other hand, we can see a positive example in the area of electronic prescriptions. During COVID-19 pandemic people who have been ill could benefit from the new system of electronic prescription (in effect since 1 December 2019). People could get their medication according to a message in a mobile phone/e-mail/data box without visiting a doctor, but after previous (telephonic or e-mail) contact with him/ her. This was used very often and such a possibility was really welcomed.

Electronic prescriptions are available in Slovakia and also in Hungary. In Hunga$r y$, it was a fortunate coincidence that the "single health service system" started to work just at the beginning of the pandemic. It handles patient documentation and prescriptions, so telemedicine, i.e. the remote provision of some health services could start, as people could get their medication directly in the pharmacy without going to the doctor and having them prescribed through personal contact. For chronic patients this is a great relief not having to go to the doctor regularly only for the prescription - as well as for all patients being able to avoid collecting their documents personally when being sent to further medical examination or getting the results of e.g. laboratory examinations.

On this wide basis, in Hungary the pandemic rather meant an incentive for the use of electronic communication in fields where it is not obligatory. This is maybe the most evident in the communication of local self-governments, which started to use electronic communication in a more systematic way. Their communication with the legal supervising authority was also channelled to electronic communication. The decrees of quite many local governments have been included into the national legal database.

In Poland, there is a possibility to organize electronic public hearings within administrative proceedings. It depends on technical possibilities of parties and the public authority; however, the public authority should accept the motion from a party. According to the jurisprudence of administrative courts, if there is a possibility for public authority to organize an electronic public hearing, a public authority's short response in which it does not approve the motion of an individual is not sufficient. ${ }^{40}$ There should be more severe grounds for rejection, composed e.g. with difficulties in discovery proceedings. In reality, many administrative authorities resign from this possibility from the grounds of the authorship law. Only an insufficient amount of public bodies, like universities, have assigned agreements with owners of electronic platforms to use it legally.

39 We have to add that the supreme courts of Hungary were previously also opposed to the use of videoconference tools. Decision No. 369/E/2009. of the Constitutional Court of Hungary (ABH 2009, 2722), as well as Decision No. Köf. 5003/2012/9. of the Municipal Council of the Kúria (the Supreme Court), at <https://kuria-birosag.hu/hu/onkugy/kof500320129-szamu-hatarozat>, accessed 26 February 2021.

40 A judgment of the Voivodeship Administrative Court in Łódź from 30 December 2020, signature III SAB/td 23/20. At <orzeczenia.nsa.gov.pl>, accessed 23 February 2021. 


\subsection{Other areas of public life affected by the COVID-19 pandemic}

COVID-19 pandemic negatively affected the Czech Republic administration. However, it is interesting to notice that from the legal point of view, the most significant legal intervention regarding the everyday functioning of public administration and the system of administrative bodies was the extraordinary measure of the Ministry of Health issued on the basis of Act No. 258/2000 Coll. on the Protection of Public Health ${ }^{41}$ that came into effect on 24 March 2020. It resulted in a certain limitation of the performance of public administration based on the fact that a state of emergency was declared with effect from 12 March 2020. ${ }^{42}$ Administrative bodies have generally been required to replace personal contact with persons. Instead of personal contact, written, electronic or telephone contact was required where possible. Administrative bodies adapted to this change. Furthermore, it was required that administrative bodies receive documents exclusively through filling offices, with preference given to electronic forms of communication. The most significant impact was the range of office hours (earmarked days of the week when officials are available to communicate face to face with the public). The office hours have been limited to a maximum of three hours on Mondays and Wednesdays. ${ }^{43}$ Since 20 April 2020, for this purpose, another Extraordinary measure of the Ministry of Health ${ }^{44}$ has introduced a new rule in order to increase hygienic measures at administrative bodies, ensuring distances of 2 meters and the use of respiratory protective equipment.

Subsequently, this regulation was copied into individual government decrees declaring crisis measures for the duration of the state of emergency issued pursuant to the Crisis Act No. 240/2000 Coll. For the time being, the last Government Decree No. 62/2021 Coll., on the Adoption of a Crisis Measure, still maintains these restrictions, however it no longer stipulates restrictions on the office hours. Thus, each respective administrative body within its own discretion may set the office hours.

In Slovak Republic, we can also see a very interesting informal approach taken by several public administrative bodies. This approach specifically took place in the area of real estate tax. In this area, public administration has extensively used persuasive methods. This approach is justifiable by its proactive approach that fulfils status of public administration as a service to the public. It could have been used only because it does not harm any rights or interests of persons, but, on the contrary, it complements them suitably.

41 Extraordinary measure of the Ministry of Health of 23 March 2020, file number MzDR $12745 / 20203 / \mathrm{MIN} / \mathrm{KAN}$. The fact that this extraordinary measure (like many others) was announced on a day-to-day basis and published exclusively only on the official notice board of the Ministry of Health can be assessed very negatively.

42 The state of emergency was declared by Government Decree No. 194 issued as No. 69/2020 Coll. The government repeatedly extended this state of emergency for the rest of 2020 and the beginning of 2021 (until 12 April 2021).

43 This was subject to change during 2020, see e.g. Government decree issued as No. 478/2020 Coll. of 20 November 2020 that limited the scope of office hours to 2 days a week within the range of 5 hours.

44 Extraordinary measure of the Ministry of Health of 9 April 2020, file number MzDR 15757/2020-3/MIN/KAN. 
We already stated that during the first wave of COVID-19 pandemic not only tax declaration for income of natural persons had to be submitted, but also tax declaration for real estate tax. In this area, municipalities serve as tax bodies as the real estate tax is a source of municipalities own income (Balko and Králik et al. 2010, p. 358). The real estate tax is not a state tax, but a municipality tax (Sidak and Duračinská et al., 2012, p. 216).

Decisions on the real estate tax include the exact amount of tax that a person is obliged to pay. This decision has to be delivered in the paper form and into the addressee's own hands. However, this was an issue for many municipalities in Slovakia as postal delivery persons either got sick of COVID-19 or boycotted(!) delivering into addressees own hands as a means of protecting themselves from getting sick.

Many municipalities (e.g. Bratislava and Čadca) decided to deliver the decisions on the real estate tax only into the maiboxes of a person and not into their own hands. That way, the postal delivery persons stayed safe, but also decisions were delivered. The disadvantage of this approach is that municipalities had no information on when the decision was delivered and therefore could not enforce the tax itself in case a taxpayer would not pay the tax. In order to prevent this disadvantage, municipalities started an awareness campaign carried out via municipality radio services (smaller municipalities), municipality newspapers or even social media campaigns (Facebook and Instagram) (bigger municipalities).

The campaign focused on three issues. In the first one, the municipality explained why it chose this means of delivering, being it an extraordinary measure that is only a one-time solution to the pandemic. It reflected on safeguarding public health of all persons residing in the municipality and concluded that it is safer to deliver only into the mailbox and not physically. In order to encourage persons to pay the tax, the municipality also explained that taxes are their own income and disclosed which projects were carried out from last year's taxes and therefore the public benefitted from them.

In the second part, municipalities stated the exact amount of tax that a person should pay. Municipalities stated that upon the delivery of the decision, a person must pay the tax within a deadline of certain specific days (the exact number of days varied between municipalities). Since the taxpayers could have, e.g., lost their jobs during COVID-19 pandemic and could have had troubles paying the whole amount of tax, municipalities proposed a solution to this issue too. Although tax regulation does not recognise repayment schedules, municipalities stated that based on mutual agreement they will accept repayment schedules with respective taxpayers.

In the last part, municipalities informed the persons that if they do not pay the real estate tax within the set deadline, the municipality will deliver the decision on the tax again. The second delivery will be carried out into own hands in order to safeguard conditions to eventually enforce the decision. This last part was mainly informative and informed on possible negative outcomes on the taxpayer in case of refusal to pay the tax. 
We are of the opinion that in this way, municipalities took a very positive and proactive approach in solving COVID-19 pandemic and possible shortages on their incomes. They chose persuasive methods in order to inspire persons to fulfil their tax obligations by naming particular activities and services they provided from last year's tax incomes. They also offered a rescue hand by proposing repayment schedules in order for taxpayers not to be charged with committing a tax administrative offense. Lastly, they comprehensively stated possible consequences if a person refuses to pay the tax.

\section{Discussion}

Since public administration might be exercised only based on law and by means of law, ${ }^{45}$ this basic principle applies in the pandemic times, too. However, the pandemic has called for many amendments to statutes that bind the exercise of public administration within V4 countries. These adaptations to execution of public administration had to be taken in form of law, since otherwise the adaptations could interfere with rights of natural and legal persons stipulated and protected by law. The adaptations that we analysed would therefore not enjoy the protection of rule of law principle as they would be considered as unlawful arbitrariness of public administration.

Especially, measures such as new forms of communication have to be stipulated by law. One of the areas that was questioned by the pandemic was the way public administration communicates within itself and with the persons outside. In Hungary, the digitalisation of communication of public administrative bodies is well-developed which is an outcome of government's investments on the subject. Therefore, electronic administration is not uncommon. As a positive example that motivates persons to communicate with public administration electronically is also the electronic project of tax declaration for personal income revenue. Also in Czech Republic and in Poland, electronic communication has experienced significant growth during the pandemic. In Poland, parties to the proceedings were granted electronic access to administrative files without the need to set up electronic e-mail boxes. Polish legislation also enacted new methods of hybrid delivery in form of sending a scanned copy of the official document to the addressee. However, this approach is not widely used by the public as it is seen as a contradiction to the secrecy of correspondence. Regarding electronic communication, the only exception within V4 countries is Slovakia. In Slovakia, the electronic communication with public administration is not seen as a preferable way of communication by the public. There is a lack of the promotion of benefits of electronic communication in the media. As a result, only $2.1 \%$ of eligible natural persons are able to communicate electronically with public administrative bodies, which is an alarmingly low number.

45 Article 2(2) of Constitution of Slovak republic, article 2(2) of the Charter of Fundamental Rights (Czech Republic), article 7 of the Constitution of the Republic of Poland. In Hungary, this flows from the principle of rule of law, article 2(1) of the Hungarian Basic Law. 
In Slovakia and in Czech Republic, no substantial changes in legal regulation on prolonging the deadlines of administrative proceedings occurred as such legal regulation is already adopted in respective (general) Administrative Procedure Acts. However, in Slovak Republic the deadline of submission of tax declaration for income has been postponed. In Hungary, in many administrative proceedings it is sufficient now to only notify the authority about the starting of an activity and the authority has a wide margin of consideration whether to start an authorisation procedure or to accept the notification and stays lawfully inactive meaning practically the granting of the permission. However, this approach results in serious deficiencies regarding safeguards of administrative procedures, but also in judicial protection.

In Poland, we identified several changes in legal regulation that could be deemed as serious. Legislation suspended material and procedural terms for administrative proceedings and also legal actions such as complaints against inactivity of public administration were not admissible during the first wave of the pandemic. Moreover, this Polish solution might have breached the principle of legal certainty because it stated these conditions based on legislation that passed on 31 March 2020 that came into legal force on 14 March 2020, yet there is no unifying judicial decision on the matter.

During the pandemic, public administration of V4 countries started to use new technologies more widely while performing their activities. As a positive example we might mention the possibilities to conduct meetings of e.g. municipality councils (Czech Republic, Slovak Republic) or even public hearings of administrative proceedings (Poland) in an online environment by using services such as Zoom, Cisco Webex or Google Meet, etc. Since the principle of transparency could be at stake while conducting online meetings, the legislation that obliges to record and publish such meetings is appropriate (this applies to the municipality meetings and not meetings related to administrative proceedings). Also, using electronic measurements in the area of health care based on which patients are able to get their medication via electronic prescriptions is widely used and preferred (Czech Republic, Hungary, Slovak Republic). On the other hand, as a drawback we must state that not every person has suitable internet connection (traditionally secluded parts of V4 countries and elder people) to participate in such meetings. Therefore, legislation should pose effective limits to safeguard rights of persons who are unable to participate. As possibly questionable, we must mention the practice in Czech Republic where the scanning of administrative files and their subsequent use by e-mail occurred. This could be problematic in regard to cyber security in general.

In legal practice, we also encountered informal ways of coping with the pandemic. This relates to Slovak solutions regarding real estate tax. 


\section{Conclusion}

The COVID-19 pandemic hit hard in the whole world. As a result, the traditional everyday life of many people changed too. Governments all over the world introduced counter measurements that have exceeded everything this generation had ever encountered before. Their justification was quite clear - maintaining public health. Hand in hand with these measurements, legislators had to cope with their legal consequences and public administration was responsible for both adapting them and adapting to them.

Since many measurements took the form of mandatory lockdowns where people had to stay at home without a possibility to communicate with public administrative bodies, many administrative procedures faced issues of their delay. In this article, we described examples of how legislators and public administration of every V4 country faced this issue. The goal was to formulate proposals on how public administrative bodies could and should change the way they carry out administrative procedure in order to help public administrative bodies adapting to the pandemic along with maintaining the right to a fair trial within a reasonable time.

Based on provided analysis, we argue that several crucial principles bind public administration. Those principles, by their own design, have to bind public administration during the pandemic. However, the principles of rule of law and of subsidiarity of the exercise of public authority along with the right to good administration including the requirement of reasonable time were at stake. In order to meet these requirements truly, public administration took several measures. In general, the formal approach taken by respective legislators and public administrations complies with the law although there are several exceptions. However, as of today, there are no judicial decisions on the matter though they are probably near. When the informal approach was taken, it should be encouraged if it complies with the principle of subsidiarity of the exercise of public authority. This will be the case if meeting several conditions: the approach must comply with the law, it must not create any new obligations, but rather propose possible solutions to a specific situation, it shall be open to everyone and not breach the principle of transparency and equality.

Unfortunately, not all discussed issues have a simple solution. As of today, postal delivery abroad has no obvious solution, not even on European level. This issue is not tackled in EU Service Directive, neither in Regulation (EU) No 910/2014 of the European Parliament and of the Council of 23 July 2014 on electronic identification and trust services for electronic transactions in the internal market nor in Regulation (EU) 2018/1724 of the European Parliament and of the Council of 2 October 2018 establishing a single digital gateway to provide access to information, to procedures and to assistance and problem-solving services and amending Regulation (EU) No 1024/2012.

However, the pandemic could be seen not only as a threat, but also a huge challenge for public administration in the (near) future. The pandemic is truly an opportunity for public administration to ameliorate its processes and to 
catch up with digitalisation trends. These should not only be focusing on the starting point (the applications) and the endpoint (the delivery of the decision) of administrative procedures. There are vast possibilities for finding better ways for the participation of the persons interested in administrative authoritative procedures and also in other fields of administrative decisionmaking procedures like planning. These are essentials in the era of good governance. So far, no attention was given to these aspects except for the Polish possibility of online public hearings. This may be due to the fact that the pandemic was anticipated not to last for so long. Maybe it is time to adapt a strategic vision and see the first waves of the COVID-19 pandemic only as an initial impact. 


\section{References}

Al Amern et al. (2020). An Introduction to the Legal Research Method: To Clear the Blurred Image on How Students Understand the Method of the Legal Science Research. At <https://www.researchgate.net/profile/Emad-AlAmaren/publication/343625989_An_Introduction_to_the_Legal_Research_ Method_To_Clear_the_Blurred_Image_on_How_Students_Understand_the Method_of_the_Lègal_Science_Research/links/5F3c903a299bf13404ced6fö/ An-Introduction-to-the-Legal-Research-Method-To-Clear-the-Blurred-Imageon-How-Students-Understand-the-Method-of-the-Legal-Science-Research. pdf>, accessed 12 April 2021.

Allen, T. (2020). Can We Really Ban In-Person Attendance at Board Meetings During the Coronavirus Emergency? At <https://canons.sog.unc.edu/ can-we-really-ban-in-person-attendance-at-board-meetings-during-thecoronavirus-emergency/\#utm_source=rss\&utm_medium=rss\&utm_ campaign=can-we-really-ban-in-person-attendance-at-board-meetingsduring-the-coronavirus-emergency>, accessed 12 April 2021.

Ansell, C., Sørensen E. and Torfing, J. (2020). The COVID-19 pandemic as a game changer for public administration and leadership? The need for robust governance responses to turbulent problems. Public Management Review, 1-12.

Balko, L. et al. (2010). Finančné právo. Bratislava: Vydavatel'ské oddelenie PraF UK.

Baranyi, B, Homoki, P. and Kovács, T. (2018). Kommentár az Elektronikus ügyintézésről szóló törvényhez. Wolters Kluwer: Budapest.

Barabás, G., Baranyi, B. and Fazekas, M. (2018). Kommentár az általános közigazgatási rendtartáshoz. Wolters Kluwer: Budapest.

Binder, K. et al. (2020). States of emergency in response to the coronavirus crisis: Situation in certain Member States. At <https://www.europarl.europa. eu/RegData/etudes/BRIE/2020/649408/EPRS_BRI(2020)649408_EN.pdf>, accessed 12 April 2021.

Chudik, A. et al. (2020). Economic consequences of Covid-19: A counterfactual multi-country analysis. At <https://voxeu.org/article/economic-consequencescovid-19-multi-country-analysis>, accessed 7 January 2021.

Fazekas, M. (2019). Közigazgatási Jog. Általános Rész I. $4^{\text {th }}$ edition. Eötvös: Budapest.

Di Mascio, F., Natalini, A. and Cacciatore, F. (2020). Public administration and creeping crises: insights from Covid-Pandemic in Italy. American Review of Public Administration, 50(6-7), 621-627.

F. Rozsnyai, K. and Hoffman, I. (2020). New Hungarian Institutions against Administrative Silence: Friends or Foes of the Parties? Studia luridica Lublinensia, 29(1), pp. 109-127. DOI: 10.17951/sil.2020.29.1.109-127.

Havelková, M. (2020). Metódy a formy činnosti verejnej správy v čase pandémie (1. čast'). At <https://comeniusblog.flaw.uniba.sk/2020/04/24/metody-a-formycinnosti-verejnej-spravy-v-case-pandemie-1-cast/>, accessed 8 January 2021.

Hendrych, D. et al. (2009). Správní právo: obecná část. $7^{\text {th }}$ edition. Praha: C. H. Beck.

Hoffman, I. and Balázs, I. (2021). Administrative Law in the Time of Corona(virus) - Resiliency of the Hungarian Administrative Law. Studia Iuridica Lublinensia, 30(1), pp. 103-119. DOI: 10.17951/sil.2021.30.1.103-119.

Hutchinson, T. and Duncan, N. (2012). Defining and Describing What We Do: Doctrinal Legal Research. At <https://ojs.deakin.edu.au/index.php/dlr/article/ view/70/75>, accessed 12 April 2021. 
Kopecký, M. (2019). Správní právo: obecná část. Praha: C. H. Beck.

Košičiarová, S. (2015). Správne právo hmotné: všeobecná čast'. Plzeň: Aleš Čeněk. Machajová, J. et al. (2009). Všeobecné správne právo. $3^{\text {rd }}$ edition. Žilina: Eurokódex.

Merkl, A. (1931). Obecné právo správní. Díl první. Praha: Orbis.

Niewiadomski Z. (2010). System Prawa Administracyjnego. Tom 1. Instytucje prawa administracyjnego. Warszawa: C.H. Beck.

Pradeep, M. D. (2019). Legal Research- Descriptive Analysis on Doctrinal Methodology. In International Journal of Management, Technology, and Social Sciences (IJMTS), 4(2), 95-103. DOI: http://doi.org/10.5281/ zenodo.3564954.

Průcha, P. (2007). Správní právo: obecná část. 7th edition. Brno: Masarykova univerzita a nakladatelství Doplněk.

Rixer, Á. (2014). Introduction. In Patyi, A. and Rixer, Á, eds., Hungarian Public Administration and Administrative Law. Passau: Schenk, pp. 31-159.

Scalia, F. (2020). The reasonable balancing of rights and interests at the time of pandemic. Review of European Administrative Law, 13(4), 89-106.

Sidak, M. et al. (2012). Finančné právo. Bratislava: C. H. Beck.

Skoczylas A. and Piątek W. (2020). System Prawa Administracyjnego. Tom 9. Prawo procesowe administracyjne. 4th edition. Warszawa: C.H. Beck.

Skulová, S. et al. (2020). Správní právo procesní. $4^{\text {th }}$ edition. Plzeň: Aleš Čeněk. Sládeček, V. (2019). Obecné správní právo. Praha: Wolters Kluwer ČR.

Škultéty, P. et al. (1997). Správne právo hmotné: všeobecná a osobitná časté. Bratislava: Vydavatel'ské oddelenie PraF UK.

Škultéty, P. et al. (2005). Správne právo hmotné: všeobecná časté. Bratislava: Vydavatel'ské oddelenie PraF UK.

Szewczyk E. (2020). Modyfikacje postępowań administracyjnych prowadzonych w okresie stanu zagrożenia epidemicznego lub stanu epidemii, Samorząd Terytorialny, Nb 6.

Taylor, L. (2014). Writing a legal research paper: Research Methodologies. At <https://learnlawlife.co.nz/2017/08/21/writing-a-legal-research-paperresearch-methodologies/>, accessed 12 April 2021.

Tomlinson, J. et al. (2020). Judicial Review in the Administrative Court During the COVID-19 Pandemic. At <https://papers.ssrn.com/sol3/Delivery.cfm/ SSRN_ID3580367_code2240968.pdf?abstractid=3580367\&mirid=1\&type =2>, accessed 12 April 2021.

Vrabko, M. et al. (2019). Správne právo procesné: všeobecná časté. $2^{\text {nd }}$ edition. Bratislava: C. H. Beck.

Wadhia, S. S. (2020). Immigration in the Time of COVID-19. In Pistor, K. ed. Law in the Time of COVID-19. At<https://scholarship.law.columbia.edu/cgi/ viewcontent.cgi?article=1239\&context=books $>$, accessed 12 April 2021, pp. 27-34.

World Health Organisation. (2021). Coronavirus. At <https://www.who.int/ health-topics/coronavirus\#tab=tab_1>, accessed 7 January 2021.

Worster, W. T. (2014). The Inductive and Deductive Methods in Customary International Law Analysis: Traditional and Modern Approaches. At<https:// www.researchgate.net/profile/William-Worster/publication/256044106 The_Inductive_and_Deductive_Methods_in_Customary_International_Law_ 
Matej Horvat, Wojciech Piątek, Lukáš Potěšil, Krisztina F. Rozsnyai

Analysis_Traditional_and_Modern_Approaches/links/5a95bb6F45851535bc dcaf05/T̄The-Inductive-and̄-Deductive-Methods-in-Customary-InternationalLaw-Analysis-Traditional-and-Modern-Approaches.pdf>, accessed 12 April 2021. 